The INL is a

U.S. Department of Energy

National Laboratory

operated by

Battelle Energy Alliance

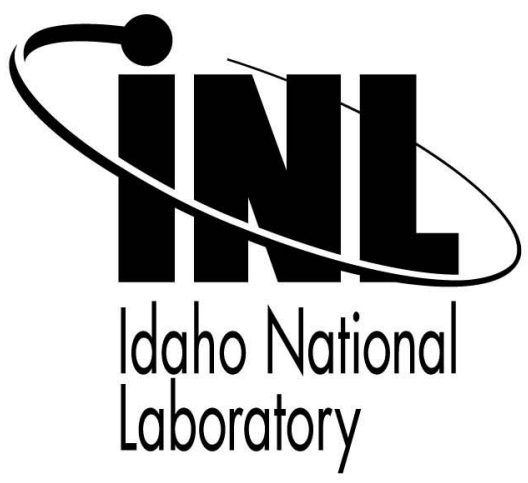

INL/CON-07-12820

PREPRINT

\section{Carbon Neutral \\ Production of Syngas Via \\ High Temperature \\ Electrolytic Reduction of \\ Steam and $\mathrm{CO}_{2}$}

\section{ASME International Mechanical Engineering Congress and Exposition}

\author{
C. Stoots \\ J. O’Brien \\ J. Hartvigsen
}

November 2007

This is a preprint of a paper intended for publication in a journal or proceedings. Since changes may be made before publication, this preprint should not be cited or reproduced without permission of the author. This document was prepared as an account of work sponsored by an agency of the United States Government. Neither the United States Government nor any agency thereof, or any of their employees, makes any warranty, expressed or implied, or assumes any legal liability or responsibility for any third party's use, or the results of such use, of any information, apparatus, product or process disclosed in this report, or represents that its use by such third party would not infringe privately owned rights. The views expressed in this paper are not necessarily those of the United States Government or the sponsoring agency. 
IMECE2007-43667

\title{
CARBON NEUTRAL PRODUCTION OF SYNGAS VIA HIGH TEMPERATURE ELECTROLYTIC REDUCTION OF STEAM AND $\mathrm{CO}_{2}$
}

\author{
C. STOOTS \\ Idaho National Laboratory \\ Idaho Falls, Idaho, USA \\ carl.stoots@inl.gov
}

\author{
J. O'BRIEN \\ Idaho National Laboratory \\ Idaho Falls, Idaho, USA \\ james.obrien@inl.gov
}

\author{
J. HARTVIGSEN \\ Ceramatec, Inc. \\ Salt Lake City, Utah, USA \\ jjh@ceramatec.com
}

\begin{abstract}
This paper presents the most recent results of experiments conducted at the Idaho National Laboratory (INL) studying coelectrolysis of steam and carbon dioxide in solid-oxide electrolysis stacks. Two 10-cell planar stacks were tested under various gas compositions, operating voltages, and operating temperatures. The tests were heavily instrumented, and outlet gas compositions were monitored with a gas chromatograph. Measured outlet compositions, open cell potentials, and coelectrolysis thermal neutral voltages compared reasonably well with a coelectrolysis computer model developed at the INL. Stack ASRs did not change significantly when switching from electrolysis to coelectrolysis operation.
\end{abstract}

\section{INTRODUCTION}

The United States is exploring the feasibility of a hydrogen-based energy economy, with the goals of reduced oil consumption, independence from foreign energy, and reduced greenhouse gas emissions. The conversion to such a hydrogenbased energy economy, however, will require decades. Synthetically-derived hydrocarbon fuels (synfuels) can offer a bridge to the future hydrogen economy and an interim solution to obtain domestic energy independence. The raw material for synfuel production is syngas, a mixture of hydrogen $\left(\mathrm{H}_{2}\right)$ and carbon monoxide (CO). Traditionally, syngas has been produced via coal gasification, and more recently by steam reforming of natural gas. Both techniques consume nonrenewables and emit greenhouse gases.

For the past several years, the Idaho National Laboratory (INL) has had an on-going project funded by the Department of Energy (DOE) under the Nuclear Hydrogen Initiative (NHI) studying nuclear-powered high-temperature electrolysis of steam using solid-oxide cells for large-scale hydrogen production [1-4]. Complementary to this research, the INL, in conjunction with Ceramatec Inc. (Salt Lake City, USA), has also been researching the use of solid oxide cells for simultaneous electrolysis (coelectrolysis) of steam $/ \mathrm{CO}_{2}$ mixtures to produce syngas:

$$
\mathrm{H}_{2} \mathrm{O}+\mathrm{CO}_{2} \longrightarrow \mathrm{H}_{2}+\mathrm{CO}+\mathrm{O}_{2} .
$$

These activities include bench scale experimentation, modeling, and flow sheet analysis $[5,6]$. When linked to a nuclear power source, this technology can provide a carbon neutral means of producing syngas while consuming $\mathrm{CO}_{2}$.

Coelectrolysis, however, is significantly more complex than simple steam electrolysis. This is primarily due to the multiple reactions that occur: steam electrolysis, $\mathrm{CO}_{2}$ electrolysis, and the reverse shift reaction (RSR):

$$
\mathrm{CO}_{2}+\mathrm{H}_{2} \leftrightarrow \mathrm{CO}+\mathrm{H}_{2} \mathrm{O} .
$$

Reaction kinetics govern the relative contributions of these three reactions. It is also important to note that the electrolysis reactions are not equilibrium reactions. The electrolyte separates the products from the reactants. However, the RSR is a kinetically fast, equilibrium reaction at high temperature in the presence of a Ni catalyst. Also, if the cell potential is high enough, $\mathrm{CO}$ can be further electrolyzed to elemental $\mathrm{C}$ :

$$
\mathrm{CO} \rightarrow \mathrm{C}+\frac{1}{2} \mathrm{O}_{2}
$$

This manuscript has been authored by Battelle Energy Alliance, LLC under Contract No. DE-AC07-051D14517 with the U.S. Department of Energy. The United States Government retains and the publisher, by accepting the article for publication, acknowledges that the United States Government retains a nonexclusive, paid-up, irrevocable, world-wide license to publish or reproduce the published form of this manuscript, or allow others to do so, for United States Government purposes. 


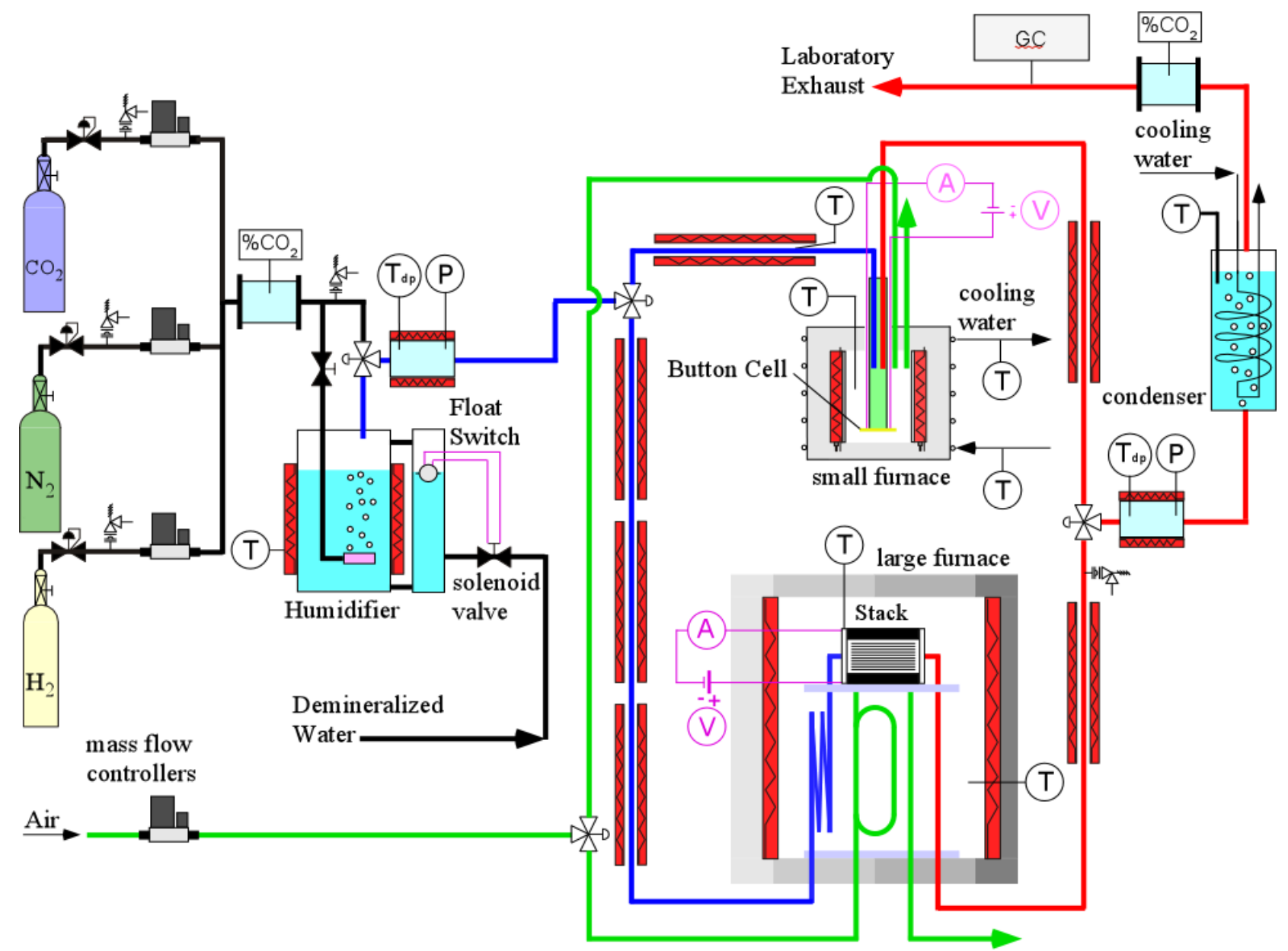

Fig. 1. Schematic of INL coelectrolysis test apparatus.

producing solid particulates that can then deposit on cell surfaces and reduce cell performance. At temperatures below $700^{\circ} \mathrm{C}$, catalytic $(\mathrm{Ni})$ formation of methane may occur $[7,8]$ :

$$
\mathrm{CO}+3 \mathrm{H}_{2} \rightarrow \mathrm{CH}_{4}+\mathrm{H}_{2} \mathrm{O}
$$

Finally, there could be material compatibility issues related to corrosion and seal leakage.

It is also feasible to produce syngas by separately electrolyzing steam and $\mathrm{CO}_{2}$. There are, however, significant advantages to electrolyzing steam and $\mathrm{CO}_{2}$ simultaneously, the primary one of which is electrical efficiency. For a given solid oxide electrolysis cell, pure $\mathrm{CO}_{2}$ electrolysis will exhibit a higher area specific resistance (ASR) than steam electrolysis. This is due to the slower overall kinetics of $\mathrm{CO}_{2}$ electrolysis and the higher overpotentials required. In coelectrolysis, the reverse gas shift reaction is relied upon for most of the $\mathrm{CO}$ production and therefore the overall electrical requirement is less. A second advantage is that in coelectrolysis the likelihood of producing carbon by electrolysis of $\mathrm{CO}$ is reduced.

The results of $\mathrm{CO}_{2} / \mathrm{H}_{2} \mathrm{O}$ electrolysis experiments performed to date using two different 10 -cell planar solid oxide stacks are presented and discussed. These results include electrolysis performance at various temperatures, gas mixtures, and electrical settings. Product gas compositions, as measured via an online micro gas chromatograph (GC), are compared to predictions obtained from a chemical equilibrium/electrolysis model. Better understanding of the feasibility of producing syngas using high temperature electrolysis may initiate the systematic investigation of nuclear-powered synfuel production as a bridge to the future hydrogen economy and ultimate independence from foreign energy resources.

\section{EXPERIMENTAL TEST FACILITY}

A schematic of the apparatus used for coelectrolysis testing at the INL is shown in Figure 1. A photograph of the test hardware follows in Figure 2. Primary components include gas supply cylinders, mass-flow controllers, a humidifier, dewpoint measurement stations, carbon dioxide concentration measurement stations, microchannel gas chromatograph, temperature and pressure measurement, high temperature furnace, and a solid oxide electrolysis cell. Nitrogen is used as an inert carrier gas. The use of a carrier gas allows for independent variation of both the partial pressures and the flow 


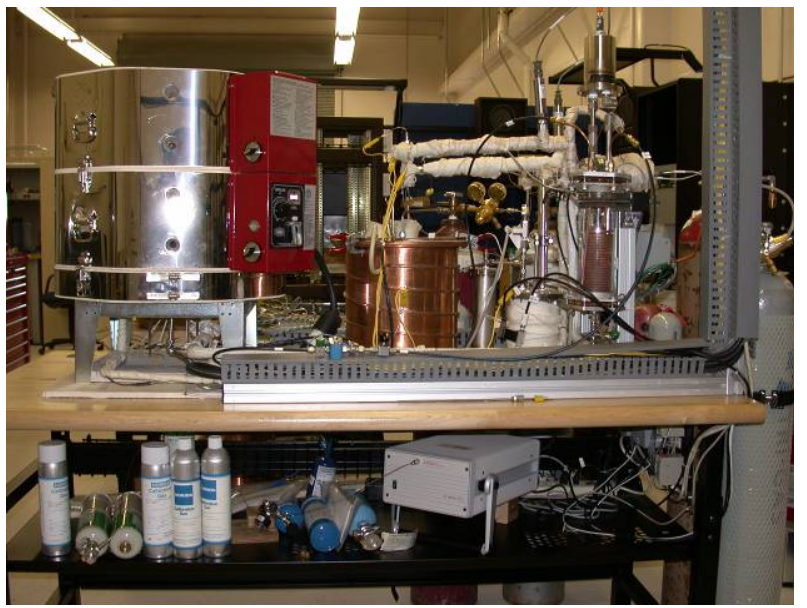

Fig. 2. Photograph of the INL coelectrolysis apparatus.

rates of the inlet steam, hydrogen, and $\mathrm{CO}_{2}$ gases while continuing to operate near atmospheric pressure. The flow rates of nitrogen, hydrogen and air are established by means of precision mass-flow controllers. The air sweep gas for the stack is supplied by the shop air system, after passing through a two-stage extractor / dryer unit.

Downstream of the mass-flow controllers, nitrogen is mixed with smaller flows of hydrogen gas and $\mathrm{CO}_{2}$. Hydrogen is included in the inlet flow as a reducing gas to prevent oxidation of the Nickel cermet electrode material. The nitrogen / hydrogen / $\mathrm{CO}_{2}$ gas mixture is mixed with steam by means of a heated humidifier. The humidifier water temperature is maintained at a constant set point value using computerized feedback control. The dewpoint temperature of the nitrogen / hydrogen $/ \mathrm{CO}_{2} /$ steam gas mixture exiting the humidifier is monitored continuously using a precision dewpoint sensor. Pressure is also measured at the dewpoint measurement stations using absolute pressure transducers. Local stream pressure information is required to determine the mole fraction of steam in the gas mixture at the dew point measurement station. These measurements have indicated that the dewpoint temperature of the gas mixture leaving the humidifier is very close to the water bath temperature, but not necessarily equal to it. Inlet $\mathrm{CO}_{2}$ concentration is also monitored using an infrared $\mathrm{CO}_{2}$ sensor. Since the vapor pressure of the water and the resulting partial pressure of the steam exiting the humidifier are determined by the water bath temperature, the water vapor mass flow rate is directly proportional to the carrier gas flow rate for a specified bath temperature. Also, since the nitrogen, hydrogen, and $\mathrm{CO}_{2}$ flow rates are fixed by the mass flow controllers, and the steam partial pressure is fixed by the bath temperature, the complete inlet gas composition is precisely known at all times. All gas lines located downstream of the humidifier are heat-traced in order to prevent steam condensation. Gas line temperatures are monitored by thermocouples and controlled by means of computer-controlled SCRs.
The inlet gas mixture is then directed to the high temperature furnace (Skutt Model KS818-3), capable of producing temperatures up to $1250^{\circ} \mathrm{C}$, which heats and maintains the electrolyzer at the appropriate test temperature via computer-based feedback control. The furnace also preheats the inlet gas mixture and the air sweep gas. A photograph of one stack, mounted on its inconel test fixture and resting on the furnace base, is shown in Fig. 3. The power leads are inconel rods insulated with alumina tubing. The steam /hydrogen $/ \mathrm{CO}_{2}$ and air sweep inlet tubes are coiled to provide additional length for heat transfer upstream of the stack. Coelectrolysis testing was performed in the temperature range of $800-830^{\circ} \mathrm{C}$.

The two stacks were fabricated by Ceramatec, Inc., of Salt Lake City, UT. The stacks have a per-cell active area of 64 $\mathrm{cm}^{2}$, for a total active area of $640 \mathrm{~cm}^{2}$ each. They are designed to operate in cross flow, with the steam /hydrogen $/ \mathrm{CO}_{2}$ gas mixture entering the inlet manifold on the right side in the photograph (Fig. 3), and exiting through the outlet manifold, visible on the left (Fig. 3). Airflow enters at the rear through an air inlet manifold, not visible in Fig. 3, and exits at the front directly into the furnace.

Fig. 4 is a close-up of the 10-cell stack air outlet plane, showing the miniature intra-cell thermocouples, voltage taps, and power lead bus bars. The power lead attachment tabs are integral with the upper and lower interconnect plates. Stack operating voltages were measured using wires that were directly spot-welded onto these tabs. Four intermediate cell voltages were monitored using small diameter wires inserted

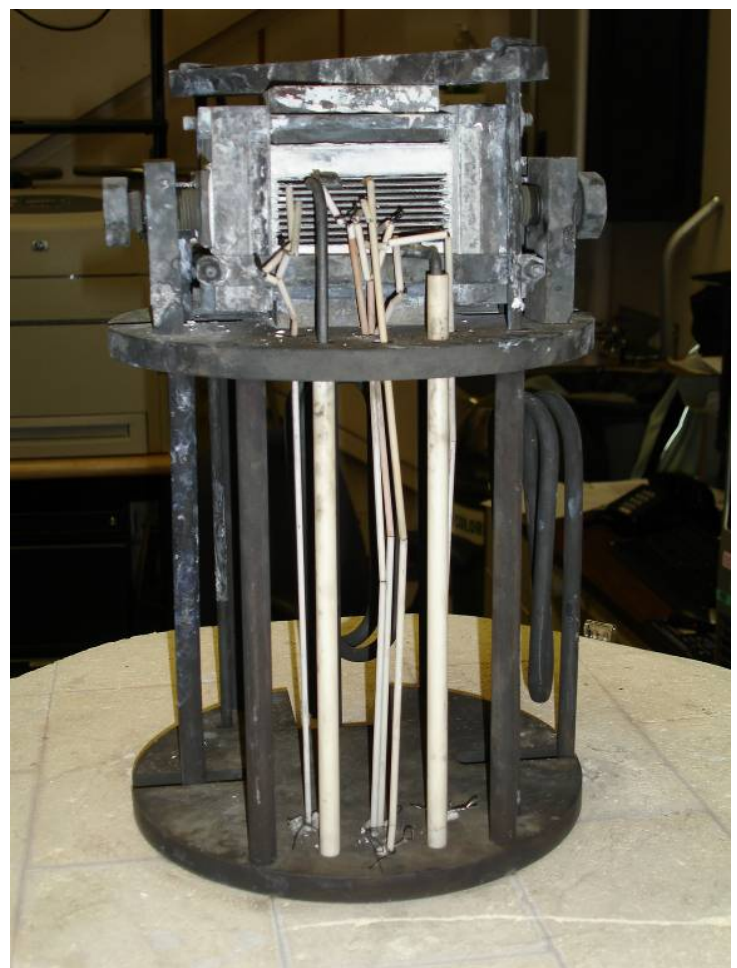

Fig. 3. One of the two 10-cell stacks mounted on test fixture on furnace base, ready to test. 


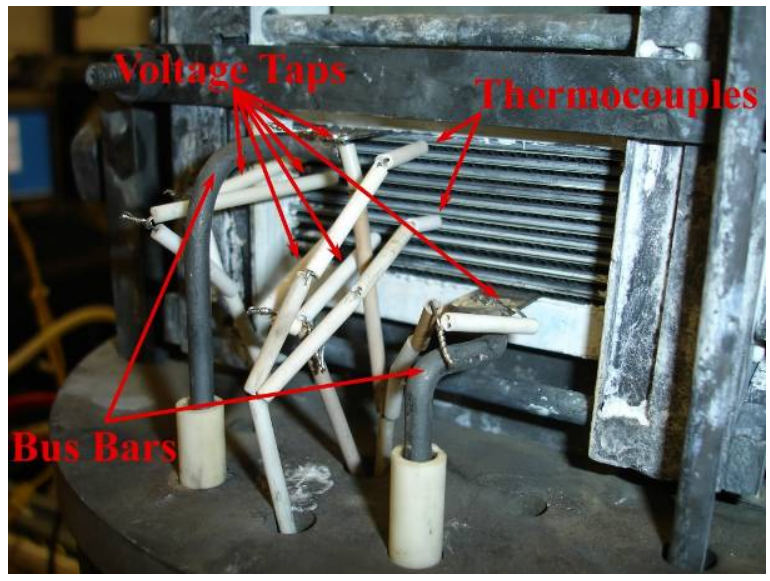

Fig. 4. Close-up of 10-cell stack, showing intra-cell thermocouples, voltage leads, and power leads.

into the airflow channels. In addition, two miniature thermocouples were inserted into the airflow channels to monitor internal stack temperatures. These were inconelsheathed, 0.020 in. $(500 \mu \mathrm{m})$ OD, mineral-insulated, ungrounded, type-K thermocouples. Thermocouple \#1 was located centrally on the top cell (cell \#1) and thermocouple \#2 was located centrally on the sixth cell from the top.

The internal components of the stack are comprised as follows. The interconnect plate is fabricated primarily from ferritic stainless steel. It includes an impermeable separator plate $(\sim 0.46 \mathrm{~mm}$ thick) with edge rails and two corrugated "flow fields," one on the sweep-gas side and one on the steam / hydrogen $/ \mathrm{CO}_{2}$ side. The height of the flow channel formed by the edge rails and flow fields is $1.0 \mathrm{~mm}$. Each flow field includes 32 perforated flow channels across its width to provide uniform gas-flow distribution. The steam / hydrogen / $\mathrm{CO}_{2}$ flow field is fabricated from nickel foil. The sweep flow field is ferritic stainless steel. The interconnect plates and flow fields also serve as electrical conductors and current distributors. To improve performance, the sweep-side separator plates and flow fields are surface - treated to form a rare-earth conductive oxide scale. A perovskite rare-earth coating is also applied to the separator-plate oxide scale by either screen printing or plasma spraying. On the steam / hydrogen $/ \mathrm{CO}_{2}$ side of the separator plate, a thin $(\sim 10 \mu \mathrm{m})$ nickel metal coating is applied.

The electrolyte is scandia-stabilized zirconia, $\sim 140 \mu \mathrm{m}$ thick. The sweep-side electrode (anode in the electrolysis mode) is a strontium-doped manganite. The electrode is graded, with an inner layer of manganite/zirconia $(\sim 13 \mu \mathrm{m})$ immediately adjacent to the electrolyte, a middle layer of manganite $(\sim 18 \mu \mathrm{m})$, and an outer bond layer of cobaltite. The steam / hydrogen / $\mathrm{CO}_{2}$ electrode (cathode in the electrolysis mode) is also graded, with a nickel cermet layer $(\sim 13 \mu \mathrm{m})$ immediately adjacent to the electrolyte and a pure nickel outer layer $(\sim 10 \mu \mathrm{m})$.

The syngas product stream exiting the furnace is directed towards a second dewpoint sensor and a $\mathrm{CO}_{2}$ sensor upon exiting the furnace and then to a condenser through a heattraced line. The condenser removes most of the residual steam from the exhaust. The final exhaust stream is vented outside the laboratory through the roof.

The rates of steam and $\mathrm{CO}_{2}$ electrolysis are measured via three different, independent methods: 1) electrical current through the stack, 2) the measured change in inlet and outlet steam and $\mathrm{CO}_{2}$ concentrations as measured by the on-line dew point and $\mathrm{CO}_{2}$ sensors, and 3) an on-line microchannel GC. The GC also tests for any additional electrolysis products, such as $\mathrm{CH}_{4}$, that may be produced.

Some additional discussion of the test apparatus, experimental procedures, data reduction, and the stack construction may be found in [1].

\section{CHEMICAL EQUILIBRIUM MODEL DESCRIPTION}

To understand the impact of the electrolysis reactions and the RSR discussed above, and to assist with interpretation of experimentally measured data, a chemical equilibrium coelectrolysis model was developed. This model also served to help determine the necessary inlet conditions for the range of experiments that were conducted.

The open-cell potential for the coelectrolysis system can be calculated as a function of temperature using the Nernst equation for either steam-hydrogen or for $\mathrm{CO}_{2}-\mathrm{CO}$, provided the equilibrium composition of the components is used in evaluating the equation. Therefore, the equilibrium composition must be determined first, by any appropriate method. Our coelectrolysis chemical equilibrium model determines the equilibrium composition of the system as follows.

The overall shift reaction can be represented as:

$$
a_{0}+b_{0}+c_{0}+d_{0} \rightarrow a_{1}+b_{1}+c_{1}+d_{1}
$$

where $a_{0}, b_{0}, c_{0}$, and $d_{0}$ represent the cold inlet mole fractions of $\mathrm{CO}, \mathrm{CO}_{2}, \mathrm{H}_{2}$, and $\mathrm{H}_{2} \mathrm{O}$, respectively, that are known from the inlet gas flow rate and dewpoint measurements. The unknown equilibrium mole fractions of the four species at the electrolyzer temperature, prior to electrolysis, are represented by $a_{1}, b_{l}, c_{1}$, and $d_{l}$. The three corresponding chemical balance equations for carbon, hydrogen, and oxygen are:

$$
\begin{gathered}
a_{0}+b_{0}=a_{1}+b_{1} \\
2 c_{0}+2 d_{0}=2 c_{1}+2 d_{1} \\
a_{0}+2 b_{0}+d_{0}=a_{1}+2 b_{1}+d_{1} .
\end{gathered}
$$

To complete a system of four equations and four unknowns, the equilibrium constant for the shift reaction:

$$
k_{R S R}(T)=\frac{b_{1} c_{1}}{a_{1} d_{1}}
$$


is included, where a correlation for $k_{R S R}$ as a function of temperature has been used.

Once the hot equilibrium composition is determined, the Nernst potential can be calculated from:

$$
\begin{aligned}
V_{N} & =\frac{-\Delta G_{f, H_{2} O}(T)}{2 F}-\frac{R T}{2 F} \ln \left[\left(\frac{d_{1}}{c_{1} y_{O 2}^{1 / 2}}\right)\left(\frac{P}{P_{s t d}}\right)^{-1 / 2}\right] \\
& =\frac{-\Delta G_{f, C O_{2}}(T)}{2 F}-\frac{R T}{2 F} \ln \left[\left(\frac{d_{1}}{c_{1} y_{O 2}^{1 / 2}}\right)\left(\frac{P}{P_{s t d}}\right)^{-1 / 2}\right]
\end{aligned}
$$

where $\Delta G_{f, \mathrm{H} 2 \mathrm{O}}$ and $\Delta G_{f, \mathrm{CO} 2}$ are the Gibbs free energy of formation for $\mathrm{H}_{2} \mathrm{O}$ and $\mathrm{CO}_{2}, R$ is the ideal gas constant, and $y_{O 2}$ is the mole fraction of oxygen on the sweep side of the cells $\left(y_{\mathrm{O} 2} \sim 0.21\right)$.

The electrolyzer outlet composition can be determined similarly, with one exception. The chemical balance equation for oxygen must be modified to account for the electrolytic reduction of the $\mathrm{CO}_{2} /$ steam mixture. Accordingly, the oxygen balance equation becomes:

$$
a_{1}+2 b_{1}+d_{1}=a_{2}+2 b_{2}+d_{2}+\Delta n_{O}
$$

where $\Delta n_{O}$ is the relative molar rate of oxygen removal from the $\mathrm{CO}_{2}$ / steam mixture, give by:

$$
\Delta n_{O}=\frac{I N_{\text {cells }}}{2 F \dot{N}_{\text {Tot }, \text { fuel }}} .
$$

In this equation, $I$ is the electronic current, $N_{\text {cells }}$ is the total number of cells in the stack, and $\dot{N}_{\text {Tot, fuel }}$ is the total molar flow rate on the $\mathrm{CO}_{2} /$ steam side, including any inert gas flows. So the post-electrolyzer equilibrium composition (state 2) can be determined again from simultaneous solution of three chemical balance equations and the equilibrium constant equation.

The model was verified by comparing results with experimental results for various electrolysis current values, inlet compositions, and electrolysis temperatures.

\section{DISCUSSION OF RESULTS}

Both stacks were heated under identical initial conditions: $3000 \mathrm{sccm} \mathrm{N_{2 }}$ flow rate, $497 \mathrm{sccm} \mathrm{H}_{2}$ flow rate, and an inlet gas dew point temperature of $51.8 \mathrm{C}$. However, in the case of stack \#2, once all internal stack temperatures were above $350 \mathrm{C}$ (or, after about 2 hours of heat up), $750 \mathrm{sccm}$ of $\mathrm{CO}_{2}$ was also introduced. Figures 5 and 6 show the heat-up profiles for stacks \#1 and \#2, respectively. Both stacks demonstrated remarkably similar heat-up profiles. The stacks do not exhibit an open cell potential (OCV) until above approximately 300$350 \mathrm{C}$, at which point the electrolyte begins to become an ion conductor. The orange lines represent the theoretical Nernst potentials for the gas mixtures, agreeing quite well with the measured OCVs. Of interest is that in the case of stack \#2, the

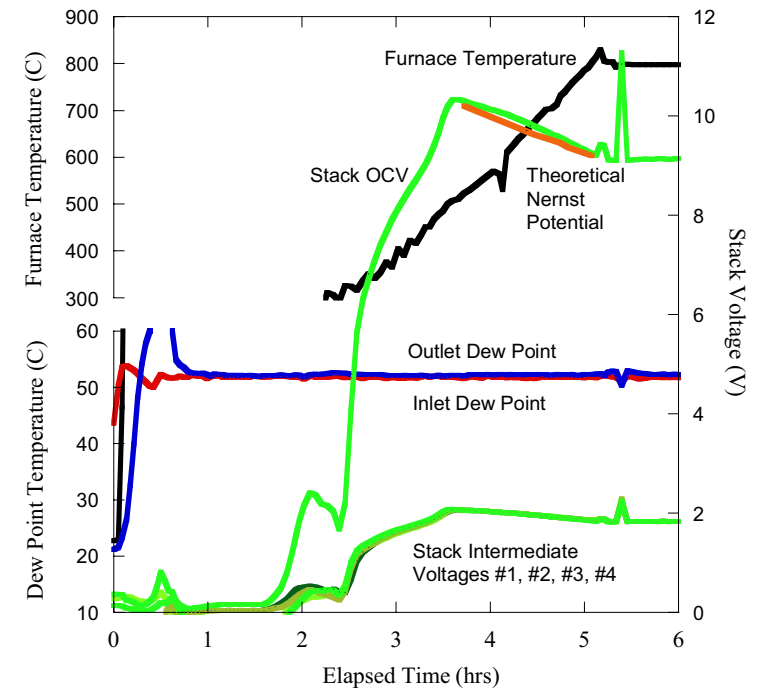

Fig. 5. Heat-up results for stack \#1.

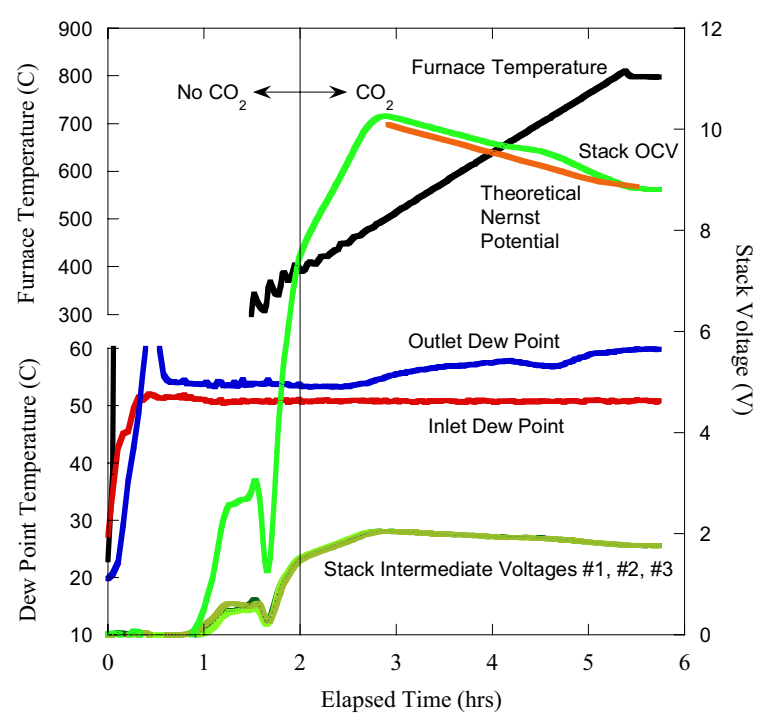

Fig. 6. Heat-up results for stack \#2.

outlet dew point temperature begins to climb as the furnace temperature exceeds $450 \mathrm{C}$, indicating that the RSR has begun to reduce $\mathrm{CO}_{2}$ and produce $\mathrm{H}_{2} \mathrm{O}$.

Cell ASR is dependent upon the type of electrolysis being conducted, with pure $\mathrm{CO}_{2}$ electrolysis exhibiting a significantly higher ASR than steam electrolysis [5]. However, in coelectrolysis the RSR is relied upon for most $\mathrm{CO}_{2}$-to- $\mathrm{CO}$ conversion, and steam electrolysis is the primary electrolytic reaction. Therefore, there is little change in ASR from steam electrolysis to coelectrolysis. To demonstrate this, polarization curves were generated for both 10-cell stacks for steam electrolysis and $\mathrm{H}_{2} \mathrm{O} / \mathrm{CO}_{2}$ coelectrolysis. Once the stacks were at an operating temperature of $800^{\circ} \mathrm{C}$, a steam electrolysis polarization curve was generated by performing a relatively fast voltage sweep $(0.3 \mathrm{~V} / \mathrm{min})$ for the conditions labeled Test 
TABLE 1. Summary of test conditions.

\begin{tabular}{|c|c|c|c|c|c|c|c|c|c|c|c|c|}
\hline \multirow[b]{2}{*}{$\begin{array}{c}\text { Test } \\
\#\end{array}$} & \multirow[b]{2}{*}{$\begin{array}{c}\text { Stack } \\
\#\end{array}$} & \multirow[b]{2}{*}{$\begin{array}{c}\text { Sweep } \\
\text { Type }\end{array}$} & \multirow[b]{2}{*}{$\begin{array}{c}\text { Stack } \\
\text { Age }\end{array}$} & \multirow[b]{2}{*}{$\begin{array}{l}\mathrm{T}_{\text {furnace }} \\
\text { (C) }\end{array}$} & \multicolumn{3}{|c|}{ Flow Rates } & \multirow{2}{*}{$\begin{array}{l}\text { Inlet } \\
\text { Dew } \\
\text { Point } \\
\text { (C) }\end{array}$} & \multicolumn{4}{|c|}{ Molar Composition } \\
\hline & & & & & $\begin{array}{c}\mathrm{H}_{2} \\
(\mathrm{sccm})\end{array}$ & $\begin{array}{c}\mathrm{CO}_{2} \\
(\mathrm{sccm})\end{array}$ & $\begin{array}{c}\mathrm{N}_{2} \\
(\mathrm{sccm})\end{array}$ & & $\begin{array}{c}\mathrm{H}_{2} \\
(\mathrm{~mol} \mathrm{\% )})\end{array}$ & $\begin{array}{c}\mathrm{CO}_{2} \\
(\mathrm{~mol} \%)\end{array}$ & $\begin{array}{c}\mathrm{N}_{2} \\
(\mathrm{~mol} \mathrm{\% )})\end{array}$ & $\begin{array}{c}\mathrm{H}_{2} \mathrm{O} \\
(\mathrm{mol} \%) \\
\end{array}$ \\
\hline 0 & 1 & Fast & Fresh & 800 & 497 & 0 & 3010 & 51.5 & 12.0 & 0 & 72.6 & 15.4 \\
\hline 1 & 1 & Fast & Fresh & 800 & 497 & 605 & 3010 & 51.5 & 10.2 & 12.4 & 61.9 & 15.5 \\
\hline 2 & 1 & Slow & Fresh & 800 & 497 & 605 & 3010 & 51.5 & 10.2 & 12.4 & 61.9 & 15.5 \\
\hline 3 & 1 & Slow & Fresh & 800 & 497 & 505 & 2510 & 45.5 & 12.6 & 12.7 & 63.3 & 11.4 \\
\hline 4 & 1 & Slow & Fresh & 800 & 497 & 705 & 1010 & 66.0 & 15.6 & 22.2 & 31.8 & 30.4 \\
\hline 5 & 1 & Slow & Fresh & 800 & 497 & 756 & 3010 & 74.0 & 6.7 & 10.1 & 40.2 & 43.0 \\
\hline 6 & 1 & Slow & Fresh & 828 & 497 & 605 & 3011 & 51.5 & 10.2 & 12.4 & 61.9 & 15.5 \\
\hline 7 & 1 & Slow & Fresh & 828 & 497 & 756 & 3513 & 65.3 & 7.3 & 11.2 & 52.0 & 29.5 \\
\hline 8 & 2 & Fast & Fresh & 800 & 450 & 0 & 1413 & 75.3 & 13.2 & 0 & 41.4 & 45.4 \\
\hline 9 & 2 & Fast & Fresh & 800 & 449 & 753 & 1414 & 59.8 & 13.2 & 22.2 & 41.6 & 23.0 \\
\hline 10 & 2 & Fast & Fresh & 800 & 334 & 564 & 1064 & 59.7 & 13.1 & 22.2 & 41.8 & 22.9 \\
\hline 11 & 2 & Fast & Fresh & 800 & 213 & 378 & 710 & 60.7 & 12.4 & 22.1 & 41.5 & 24.0 \\
\hline 12 & 2 & Slow & $1 \mathrm{Week}$ & 800 & 449 & 753 & 1414 & 59.8 & 13.2 & 22.2 & 41.6 & 23.0 \\
\hline 13 & 2 & Slow & $1 \mathrm{Week}$ & 800 & 334 & 564 & 1064 & 59.7 & 13.1 & 22.2 & 41.8 & 22.9 \\
\hline 14 & 2 & Slow & 1 Week & 800 & 213 & 378 & 710 & 60.7 & 12.4 & 22.1 & 41.5 & 24.0 \\
\hline 15 & 2 & Slow & 1 Week & 830 & 497 & 756 & 3513 & 65.3 & 7.4 & 11.2 & 52.0 & 29.4 \\
\hline 16 & 2 & Slow & 2 Weeks & 800 & 450 & 752 & 1410 & 60.3 & 13.2 & 22.0 & 41.3 & 23.5 \\
\hline 17 & 2 & Slow & 2 Weeks & 800 & 334 & 564 & 1064 & 60.2 & 13.0 & 22.0 & 41.5 & 23.5 \\
\hline 18 & 2 & Slow & 2 Weeks & 800 & 213 & 378 & 710 & 60.7 & 12.4 & 22.1 & 41.5 & 24.0 \\
\hline 19 & 2 & Slow & 2 Weeks & 830 & 497 & 756 & 3513 & 65.3 & 7.4 & 11.2 & 52.0 & 29.4 \\
\hline
\end{tabular}

$\# 0$ and Test \#8 in Table 1. This same voltage sweep was repeated for the coelectrolysis conditions Test \#1 and Test \#9, 10, and 11. These results are shown in Figure 7 for stack \#1 and Figure 8 for stack \#2. Using these data, the sweep-average apparent ASR was calculated by numerically averaging the voltage and current data:

$$
A S R=\sum \frac{1}{n} \frac{\left(V_{o p}-V_{O C}\right) / N_{c e l l s}}{I / A_{\text {cell }}}
$$

where $n$ is the number of measurements included, $V_{o p}$ is the operating voltage, $V_{o c}$ is the measured open cell potential, and $A_{\text {cell }}$ is the active area of each cell $\left(64 \mathrm{~cm}^{2}\right)$. For Test $\# 0$ the steam electrolysis sweep data above 6 A current exhibited a large amount of scatter, possibly due to local steam starvation, and was not included in the apparent ASR calculations. Similarly, the nonlinearity in the Test \#11 polarization curve is also due to local starvation, caused by the low gas flow rates and hence reduced amount of steam supplied to the stack. Overall, there was almost no change in apparent ASR for coelectrolysis versus steam electrolysis, reinforcing the hypothesis that steam electrolysis is the principal electrolysis reaction and that the RSR is mostly responsible for CO production. ASR values tended to increase with decreasing steam availability.

Figure 9 presents internal stack temperature depression (the difference between the temperature measured during the sweep and the temperature at open cell conditions) for thermocouple $\# 2$ as a function of stack operating voltage for tests $\# 0,2,3,4,5,6$ and 7 listed in Table 1. With the exception of test $\# 0$, these tests were slow sweeps. This means that the stack was allowed to reach thermal and chemical equilibrium at each sweep voltage set point. This usually required 10 minutes for each setting.

Steam electrolysis, $\mathrm{CO}_{2}$ electrolysis, and the RSR are endothermic reactions that tend to depress the cell temperature during electrolysis. However, the cell ohmic heating tends to increase the cell temperature, proportional to the square of the current. These two effects balance each other at the thermal neutral voltage. At operating voltages below thermal neutral, the endothermic heat of reaction dominates and the cell temperature is lower than that at open cell. At operating voltages above thermal neutral, ohmic heating dominates and the cell temperature will exceed that at open cell. For pure steam electrolysis, the thermal neutral voltage is a weak function of temperature only and is equal to $1.287 \mathrm{~V}$ at $800^{\circ} \mathrm{C}$ and $1.288 \mathrm{~V}$ at $830^{\circ} \mathrm{C}$. For coelectrolysis, however, the thermal neutral voltage is also a function of gas composition. By curve fitting the experimental data (shown as lines in Figure 9) and solving for zero temperature depression, experimental thermal neutral voltages were estimated. Experimental open cell potentials were directly measured. To predict the theoretical open cell potentials and thermal neutral voltages, the chemical equilibrium coelectrolysis model discussed above was extended to include an energy balance. This more complex model is discussed in Ref. 6. Table 2 summarizes the measured versus predicted open cell potentials and thermal neutral voltages for the experimental conditions listed in Table 1. The average 
TABLE 2. Comparison of measured versus predicted open cell potentials and thermal neutral voltages.

\begin{tabular}{|c|c|c|c|c|}
\hline $\begin{array}{c}\text { Test } \\
\#\end{array}$ & \multicolumn{2}{|c|}{$\begin{array}{c}\text { Open Cell Potential } \\
\text { (volts per cell) }\end{array}$} & \multicolumn{2}{c|}{$\begin{array}{c}\text { Thermal Neutral } \\
\text { Voltage } \\
\text { (volts per cell) }\end{array}$} \\
\hline & Measured & Predicted & Measured & Predicted \\
\hline 2 & 0.8795 & 0.8923 & 1.3004 & 1.3437 \\
\hline 3 & 0.8959 & 0.9082 & 1.3231 & 1.3476 \\
\hline 4 & 0.8700 & 0.8826 & 1.3271 & 1.3446 \\
\hline 5 & 0.8392 & 0.8421 & 1.3017 & 1.3161 \\
\hline 6 & 0.8696 & 0.8803 & 1.3447 & 1.3451 \\
\hline 7 & 0.8376 & 0.8471 & 1.3265 & 1.3285 \\
\hline
\end{tabular}

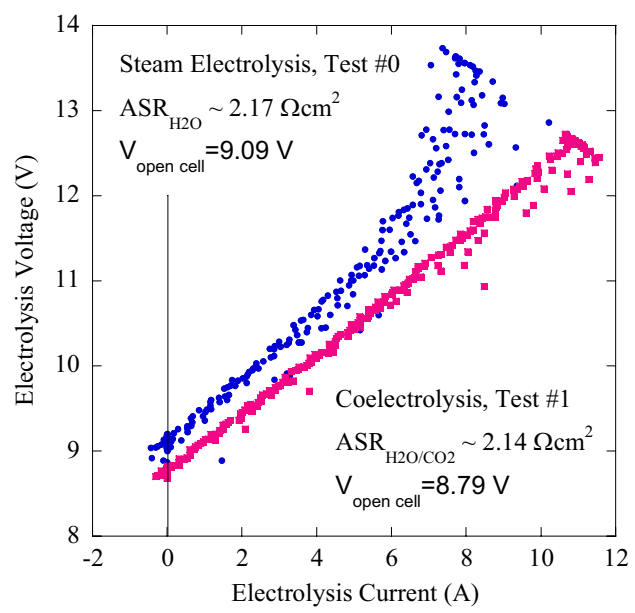

Fig. 7. Fast sweep polarization curves for stack \#1, steam electrolysis and coelectrolysis (Tests \#0 and 1), with mean ASR values.

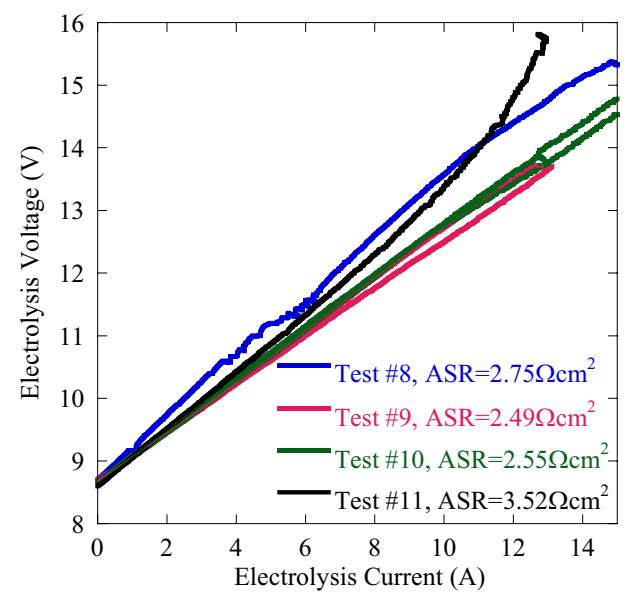

Fig. 8. Fast sweep polarization curves for stack $\# 2$, steam and coelectrolysis (Tests \#8, 9, 10, and 11), with mean ASR values.

difference between measured and predicted thermal neutral voltages for the 6 coelectrolysis tests conducted was $17 \mathrm{mV}$.

All testing performed on stack \#1 occurred while the stack was relatively new or fresh. Testing on stack \#2, however, was staged over a 2 week period. Tests 8 through 11 were

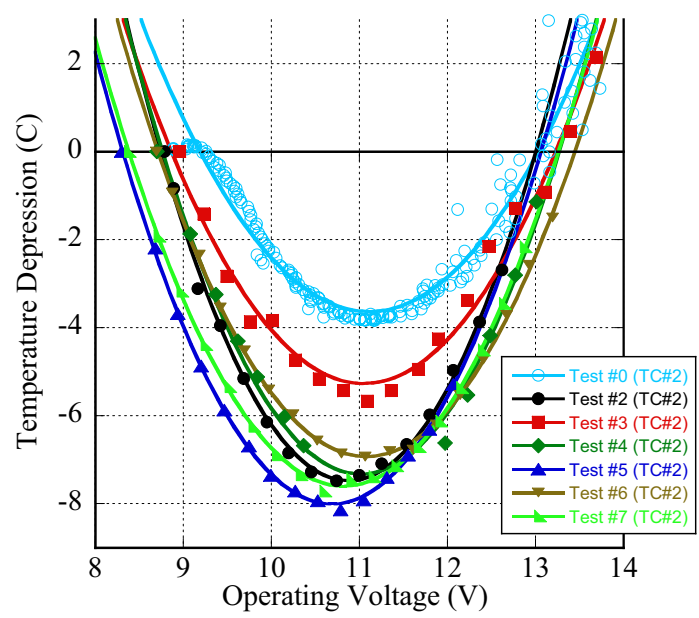

Fig. 9. Internal stack temperatures for stack \#1 (thermocouple \#2) for various test conditions.

performed while stack \#2 was fresh. After test \#11, the stack was left under load for one week. Tests 12 through 15 were then performed. The stack was once again left under load for one week, and then tests 16 through 19 were performed. Upon conclusion of test 19, the stack was allowed to cool. A time trace of testing for stack \#2 is shown in Figure 10. Several disruptions in gas flow (days 0,2 , and 13), loss of $\mathrm{CO}_{2}$ (day 9), and loss of the power supply (day 13) contributed to accelerated aging of the stack.

Figure 11 depicts the polarization curves for tests 12 through 19. Tests 12 through 15 were conducted after stack \#2 had been under load for 1 week. Tests 16 through 19 are identical to tests 12 through 15 , respectively, except that they were conducted after the stack had been under load for 2 weeks. In each case there is a marked increase in the sweep ASRs, due to stack degradation as well as the disruptions

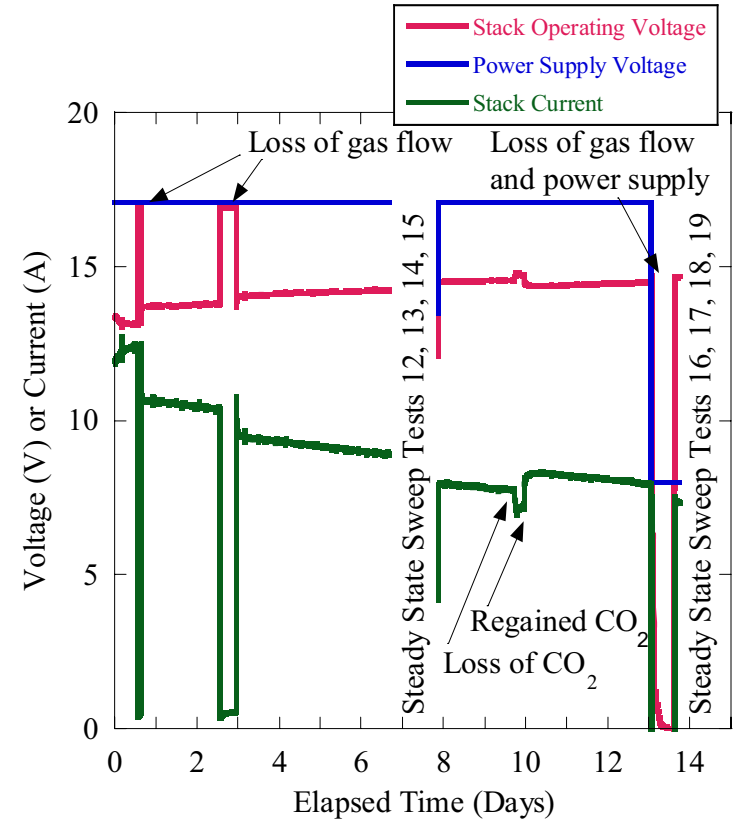

Fig. 10. Time history for stack $\# 2$ testing. 


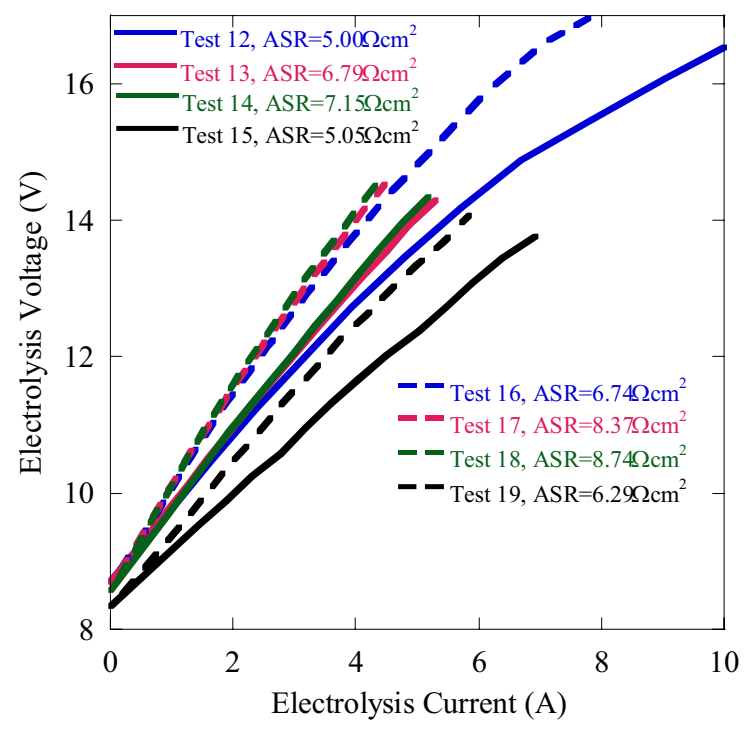

Fig. 11. Polarization curves for stack \#2. Solid lines are at 1 week age, dashed are at 2 weeks age..

discussed above. All the tests shown on Figure 11 were conducted at a furnace temperature of $800 \mathrm{C}$ with the exception of tests 15 and 19, which were conducted at $830 \mathrm{C}$. ASR values tended to increase with decreasing total gas flow rate, due to lower available steam at lower total gas flow rates. Tests 15 and 19 exhibit lower ASRs due to the higher operating temperature, and resulting higher electrolyte ionic conductivity.

Figs. 12-17 present the compositions of steam, $\mathrm{CO}_{2}$, hydrogen, and $\mathrm{CO}$ as a function of electrolysis current on a dry basis for stack \#1, tests 2-7. Lines represent various model predictions and symbols represent experimental measurements. The effects of varying the equilibrium temperature used in the chemical equilibrium coelectrolysis model for the conditions of Test \#1 are shown in Fig. 12. The RSR equilibrium constant is a function of temperature, as shown in Equation (9). Since product gases cool to room temperature before analysis in the micro GC, it was not certain what value to use for an "apparent" equilibrium temperature for the products. Therefore, the chemical equilibrium coelectrolysis model was run for several different equilibrium temperatures ranging from $650^{\circ} \mathrm{C}$ to $800^{\circ} \mathrm{C}$. It was found that setting the chemical equilibrium coelectrolysis model equilibrium temperature equal to the furnace temperature produced the best comparisons, indicating that the products are kinetically frozen after they leave the hot zone, probably due to lack of any significant catalyst surface and the cool-down is fairly rapid. Predicted compositions were therefore evaluated at the electrolyzer temperature for all subsequent evaluations (Figures 13 through 17).

Figures 12 through 17 demonstrate that even at zero current there was a drop in $\mathrm{CO}_{2}$ and $\mathrm{H}_{2}$ mole fractions from the cold inlet values, with $\mathrm{CO}$ produced. This is solely due to the RSR. As the electrolysis current was increased, the yield of syngas increased linearly while the concentration of $\mathrm{CO}_{2}$ (and $\mathrm{H}_{2} \mathrm{O}$, not shown in the figures) decreased. These figures also show overall good agreement between experimental GC data and results from the chemical equilibrium coelectrolysis model for the range of testing performed in this study. Finally, in the case of Test \#7, at the maximum current studied the product $\mathrm{H}_{2}$ concentration was doubled and product $\mathrm{CO}_{2}$ concentration was reduced to half that of the process inlet mixture.

\section{CONCLUSIONS}

Synthetically-derived hydrocarbon fuels can offer an interim solution for domestic energy dependence and a bridge to the hydrogen economy. The raw material for synfuel production is syngas, a mixture of $\mathrm{H}_{2}$ and $\mathrm{CO}$. The Idaho National Laboratory has demonstrated the feasibility of using high temperature solid oxide cells to coelectrolyze $\mathrm{H}_{2} \mathrm{O}$ and $\mathrm{CO}_{2}$ simultaneously to produce syngas. Two 10-cell planar stacks were tested under various gas compositions, operating voltages, and operating temperatures. Both stacks' open cell potentials matched theoretical Nernst values during heat up. Similarly, open cell potentials and thermal neutral voltages measured during testing compared well with computer model predictions. Stack ASR values did not vary significantly when switching from steam electrolysis to steam $/ \mathrm{CO}_{2}$ electrolysis. Stack ASR values showed trends of increasing with lower steam availability and stack age. There was overall good agreement between experimental gas chromatograph data for outlet compositions and results from the chemical equilibrium coelectrolysis model. These measurements and model results indicate that coelectrolysis effectively increases the syngas yield for a given steam $/ \mathrm{CO}_{2}$ process stream. Overall, the coelectrolysis process appears to be a promising technique for large-scale syngas production. 


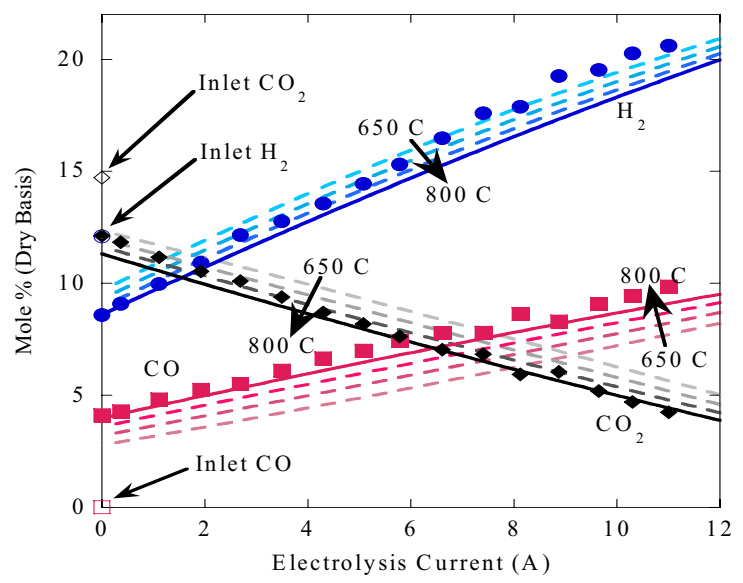

Fig. 12. Effect of varying chemical equilibrium coelectrolysis model equilibrium temperature (Eq. 9) with comparison to Test 2 experimental data.

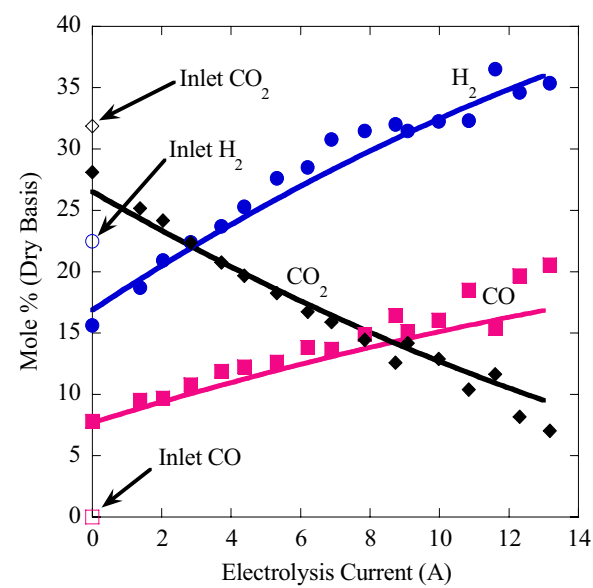

Fig. 14. Test 4 experimental and chemical equilibrium coelectrolysis model results, $T_{\text {equil }}=800 \mathrm{C}$.

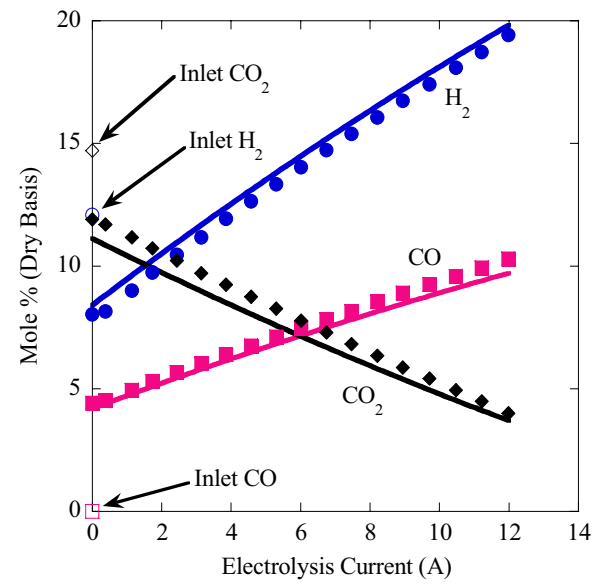

Fig. 16. Test 6 experimental and chemical equilibrium coelectrolysis model results, $T_{\text {equil }}=828 \mathrm{C}$.

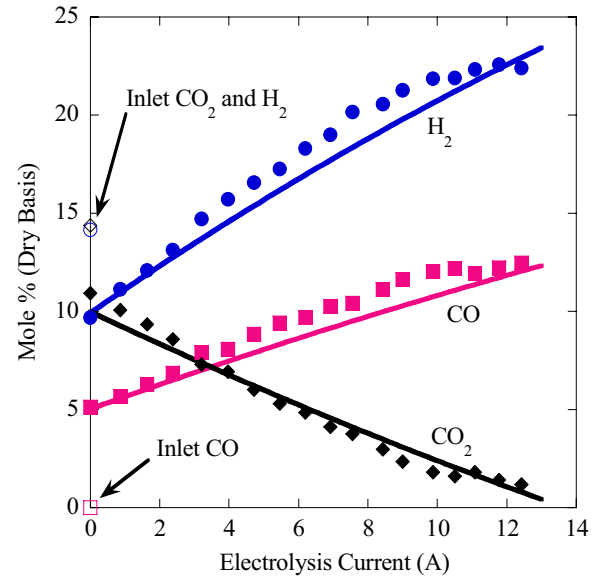

Fig. 13. Test 3 experimental and chemical equilibrium coelectrolysis model results, $T_{\text {equil }}=800 \mathrm{C}$.

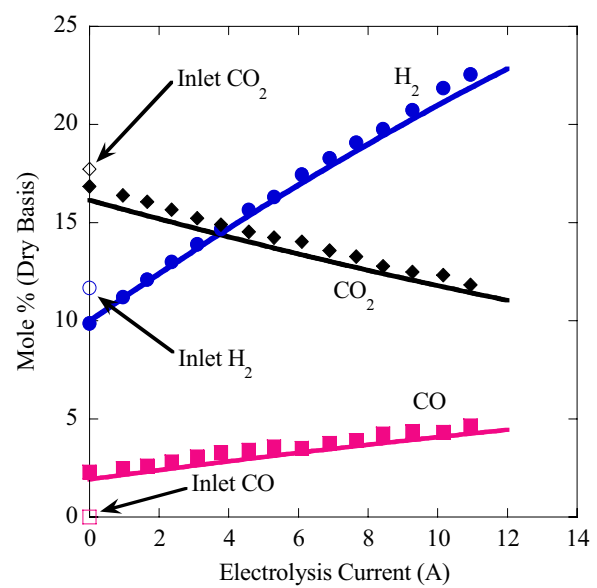

Fig. 15. Test 5 experimental and chemical equilibrium coelectrolysis model results, $T_{\text {equil }}=800 \mathrm{C}$.

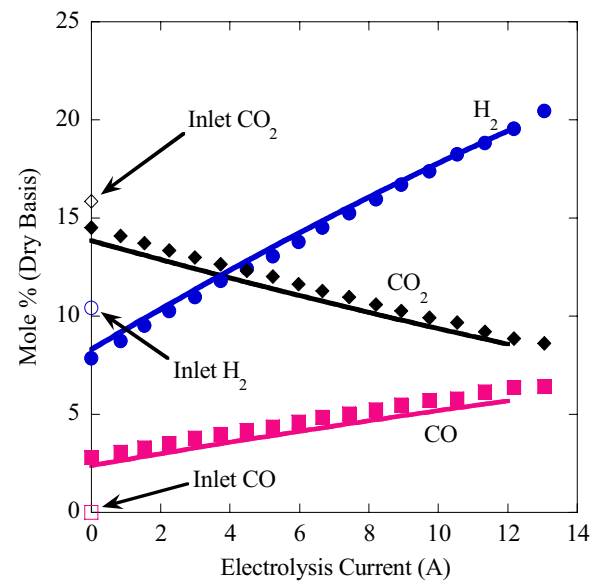

Fig. 17. Test 7 experimental and chemical equilibrium coelectrolysis model results, $T_{\text {equil }}=828 \mathrm{C}$. 


\section{NOMENCLATURE}

$\begin{array}{ll}a, b, c, d & \text { mole fractions } \mathrm{CO}, \mathrm{CO}_{2}, \mathrm{H}_{2}, \text { and } \mathrm{H}_{2} \mathrm{O} \text { respectively } \\ A_{\text {cell }} & \text { active area of each cell, } \mathrm{cm}^{2} \\ A S R & \text { apparent area specific resistance, } \mathrm{Ohm} \mathrm{cm} \mathrm{cm}^{2} \\ F & \text { Faraday's constant, } 96487 \mathrm{~J} / \mathrm{V} \text { mol } \\ \Delta G_{f} & \text { Gibbs free energy of formation, } \mathrm{J} / \mathrm{mol} \\ I & \text { total electronic current, } \mathrm{A} \\ k_{R S R} & \text { Reverse Shift Reaction equilibrium constant } \\ n & \text { number of measurements } \\ \Delta n_{0} & \text { relative molar rate of oxygen removal from the } \\ & \text { CO } / \text { steam side, mol/s } \\ N_{c e l l s} & \text { total number of cells in the stack } \\ N_{T o t,} \text { fuel } & \text { total molar flow rate on } \mathrm{CO}_{2} / \mathrm{steam} \mathrm{side} \mathrm{of} \mathrm{cells,} \\ & \text { mol/s } \\ P & \text { pressure, Pa } \\ P_{s t d} & \text { standard pressure, Pa } \\ R & \text { universal gas constant, } \mathrm{J} / \mathrm{mol} \mathrm{K} \\ T & \text { temperature, } \mathrm{K} \\ V_{N} & \text { Nernst potential, } \mathrm{V} \\ V_{O C} & \text { stack open cell potential, } \mathrm{V} \\ V_{o p} & \text { stack operating voltage, } \mathrm{V} \\ y & \text { mole fraction }\end{array}$

\section{ACKNOWLEDGMENTS}

This work was supported by the Idaho National Laboratory, Laboratory Directed Research and Development program and the U.S. Department of Energy, Office of Nuclear Energy, Nuclear Hydrogen Initiative Program.

\section{REFERENCES}

[1] O’Brien, J. E., Stoots, C. M., Herring, J. S., and Hartvigsen, J. J.,"Hydrogen Production Performance of a 10Cell Planar Solid-Oxide Electrolysis Stack," Journal of Fuel Cell Science and Technology, Vol. 3, pp. 213-219, May, 2006.

[2] O’Brien, J. E., Stoots, C. M., Herring, J. S., and Hartvigsen, J. J., "High Temperature Electrolysis for Hydrogen Production from Nuclear Energy," invited paper for a NURETH11 Special Edition, Nuclear Technology, 2006.

[3] Hawkes, G. L., O’Brien, J. E., Stoots, C. M., Herring, J. S., "CFD Model of a Planar Solid Oxide Electrolysis Cell fro Hydrogen Production from Nuclear Energy," invited paper for a NURETH11 Special Edition, Nuclear Technology, 2006.

[4] Herring, J. S., O’Brien, J. E., Stoots, C. M., and Hawkes, G. L., "Progress in High-Temperature Electrolysis for Hydrogen Production using Planar SOFC Technology," International Journal of Hydrogen Energy, 2006.

[5] Stoots, C.M., O’Brien, J.E., Hawkes, G.L., Herring, J.S., Hartvigsen, J.J, "High Temperature Co-Electrolysis of H2O and CO2 for Syngas Production," 2006 Fuel Cell Seminar, Honolulu, Hawaii, Nov. 13-17, 2006, paper no. 418.

[6] Hawkes, G.L., O’Brien, J.E., Stoots, C.M., Jones, R., "Three Dimensional CFD Model of a Planar Solid Oxide Electrolysis Cell for Co-Electrolysis of Steam and CarbonDioxide," 2006 Fuel Cell Seminar, Honolulu, Hawaii, Nov. 1317, 2006, paper no. 298.

[7] S.H. Jensen, J.V.T. Høgh, R. Barfod, M. Mogensen, "High temperature electrolysis of steam and carbon dioxide," In Energy technologies for Post Kyoto targets in the medium term, Proceedings of Risø International Energy Conference, Risø, Denmark, May 19-21, 2003.

[8] S.H. Jensen, and M. Mogensen, "Perspectives of High Temperature Electrolysis Using SOEC," $19^{\text {th }}$ World Energy Congress 2004, Sydney, Australia, September 5-9, 2004. 